Egyptian Journal of Aquatic Biology \& Fisheries

Zoology Department, Faculty of Science,

Ain Shams University, Cairo, Egypt.

ISSN $1110-6131$

Vol. 23(5): 135 - 146 (2019)

www.ejabf.journals.ekb.eg

\title{
Recycling of Al (III) from Solid Waste as Alum and Alum Derivatives and their Applications in Water and Waste water Treatment
}

\author{
F. M. Mohamed ${ }^{1}$, A. M. Kamal ${ }^{2}$ and K.A. Alfalous ${ }^{3}$ \\ 1- Faculty of Earth Sciences, Beni-Suef University, Egypt \\ 2- Faculty of Science, South Valley University, Egypt. \\ 3- Faculty of science, Alasmarya Islamic University, Libya \\ * Corresponding author: fathy732005@yahoo.com
}

\section{ARTICLE INFO}

Article History:

Received: Oct. 25, 2019

Accepted: Nov. 28, 2019

Online: Dec. 2019

Keywords:

Solid waste

Recycling

Pollution

Alum

polyhydroxy aluminum

Sewage water treatment

\section{ABSTRACT}

To avoid the water resource pollution, this study attentively of preparation, characterization of leached Alum (LA), poly aluminum hydroxy sulphate $\left(\mathrm{PAlHS}^{\mathrm{TM}}\right.$ ) and poly aluminum hydroxy sulphate silicate $\left(\mathrm{PAlHSSi}{ }^{\mathrm{TM}}\right)$, which prepared from activated silica derived from rice husk ash and Alum derived from solid waste resulted from surface water purification plant, as well as applications of these new materials in water and waste water treatment. Representative samples of solid waste were collected the solid wastes of surface water purification station. The factors affecting the output of leached (Alum) Aluminum sulphate $\left(\mathrm{Al}_{2}\left(\mathrm{SO}_{4}\right)_{3}\right.$.X $\mathrm{H}_{2} \mathrm{O}$ as $\left(\mathrm{Al}_{2} \mathrm{O}_{3}\right)$ such as the sulphuric acid concentration percentage, $\mathrm{pH}$, flux rate of $\mathrm{H}_{2} \mathrm{SO}_{4}$, and contact time were studied. The obtained Alum is converted to PAlHS ${ }^{\mathrm{TM}}$ and PAlHSSi ${ }^{\mathrm{TM}}$ which characterized using FTIR, XRD and SEM, then the two new materials were applied in sewage water treatment. The empirical outcome implied that there are no considerable deviations of dissolved ions in water specification that treated either with $\mathrm{PAlHS}^{\mathrm{TM}}$ or PAlHSSi ${ }^{\mathrm{TM}}$. Both of them conform to international guidelines. Whereas the elimination proportion of the main sewage water pollutants: total suspended solids (TSS), chemical oxygen demand (COD) and biological oxygen demand (BOD) reached 96, 89, and 90\%, respectively using PAlHS ${ }^{\mathrm{TM}}$, while the elimination proportion of the last main sewage water pollutants reached 97, 91, and 92\%, respectively using $\mathrm{PAlHSSi}^{\mathrm{TM}}$. conclusively, the prepared PAlHS ${ }^{\mathrm{TM}}$ and PAlHSSi ${ }^{\mathrm{TM}}$ and from solid waste of water purification plant should be used as a minimal cost of commercial coagulant in sewage water treatment for its quality in coagulation beside its uses in an environmental impact reducer.

\section{INTRODUCTION}

The train of conventional purification of surface water is done through different stages, starting from coarse and fine screening, initial disinfection especially chlorination, coagulation, flocculation, sedimentation, filtration, and terminus with the final disinfection (Davis et al. 2010), (Metcalf \& Eddy, 2003; 2013), , (Hu et al., 2018), (Sousa et al., 2017) (Egyptian codes for water purification (1998).

Within purification process, aluminum hydroxide sludge is created through the reaction between Alum and the alkalinity of raw water, (Bui et al., and 2017) sludge is an inescapable by-product of water and wastewater purification system. 
The world is actually undertaking an instantaneous growth in sludge production of growth the capacity of drinking water and waste water that is forecasted to increase during the next years and it would be indispensable to determine new applications for these residues.

In Egypt, the daily drinking water production is about $25,000,000 \mathrm{~m}^{3}$, each one cubic meter consumes about $10 \mathrm{gm}$ of Alum, which produces $5 \mathrm{gm}$ of Aluminum hydroxides, which released as aluminum sludge, so the annual of sludge reached 50,000 tons sludge's, this sludge is very huge and it have a hazardous effect, (MOHUUC (2019).

There are many conventional methods have been followed to dispose of this type of sludge, the $1^{\text {st }}$ method is drainage of the river (at distance $3 \mathrm{~km}$ downstream or $1 \mathrm{~km}$ upstream from intake of drinking plant, (Egyptian codes for water purification (1998). if this waste analysis agrees with Egyptian law of industrial waste which is drained in River Nile and its branches. The $2^{\text {nd }}$ is landfill, landfill has been a major option in the disposal of sewage sludge for a long time, but it is not a sustainable solution due to the increasing competition for landfill space, higher costs and stricter ecological guidelines claimed, essentially in the European nations (Gasco et al., 2005).

Coagulation or flocculation sludge comprises of a huge quantity of coagulant precursors, so the sludge as a wealth recycled from drinking water and sewage treatment systems, recycling of sludge could be an efficacious method to minimize the conduct sludge magnitude as well as economize the dose charge, (Xu et al., 2005). Mostly, there are four paths of coagulant recapture utilized for water treatment in current years, which are basification, acidification, membranes as well as ion exchange.

The fundamental of coagulation includes adding coagulant which composes aluminum hydroxide, the destabilized colloids are trammeled. Acidification involves neutralizing these flocs of hydroxide to liberate aluminum salt back in the solution in addition to some pollutants such as heavy metals, total organic carbon (TOC)......etc. Acidification is an extremely efficacious and the least price method for the capture of coagulants inter alia the four methods mentioned above. It is utilized primarily to recover metal ions from water treatment sludge at acidic media at low $\mathrm{pH}$ value. (Bishop et al., 1987), (Panswad 2007), (Fulyon,1974), ( Abdo,1993), and (Li, et al., 2005), It essentially comprises of three steps, (Fulyon,1974), and (Abdo, 1993), dewatering, acidification and separation. Some researchers stated that the efficiency of acidification to extract Alum salt from solid waste (sludge) is most effective at low $\mathrm{pH}$, ( Panswad, 2007),. Drying of sludge in sunlight instead of dewatering was applied in the work. Several researchers concentrated on the recapture of coagulants from drinking water purification plants and its reuse in drinking water purification several years earlier, (Cornwell et al., 1979), and ( Chu, (1999).

Utilization of a classical co- agulants and poly inorganic coagulant specially poly in organic fattened with activated silica gained from rice husk in waste water treatment, (Mohamed, 2009), and Abo-El-Enein, et al., 2011) or use Alum itself after extracting from sewage waste water, Chubar, 2005), (Midorkawa, 2008), and (Babatunde 2009). However, as the quality demand for drinking water is restricted, and unfavorable matters grow during coagulant recycling, it is scarce to use the recapture technique for drinking water treatment for the time being, except if the quality of raw water is high, Nile River water in Upper Egypt has high quality (especially in the area under study) which will be stated posterior in the analysis. 
Many researchers concluded that poly in organic co-agulant used in turbidity removal as well as biological oxygen demand (BOD) reduction, (Abo-El-Enein,et al., 2011) and Tolkou (2014). Whereas another researcher conformed the usage of zirconium and Chitosan in reduction of organic load, (Christensen, 2016).

Therefore the objectives of this study were focused on recycling of aluminum from solid waste from sludge of water purification plant of surface water to Alum and Alum derivatives such as poly hydroxy aluminum sulphate (PAlHS ${ }^{\mathrm{TM}}$ ) and poly hydroxy aluminum sulphate silicate $\left(\mathrm{PAlHSSi}^{\mathrm{TM}}\right)$ as well as their characterization and applications in drinking purification especially turbidity removal and sewage water treatment specially organic load reduction. The effluent of sewage water will be used in agricultural trickle irrigation techniques, where, the treatment techniques based on precipitation, coagulation and adsorption techniques by poly inorganic coagulants (PIC).

\section{MATERIALS AND METHODS}

All chemicals utilized are of merchant grade with the exception of sodium hydroxide is a lab grade product. Double distilled water was utilized to make all solutions.

\section{Preparation of Alum $\left(\mathrm{Al}_{2} \mathrm{O}_{3}\right)$ from solid waste (dried sludge)}

The dried sludge after separation from drinking water plant treated with different concentration $\mathrm{H}_{2} \mathrm{SO}_{4}$ acid solution. Factors affecting in productivity of Alum $\left(\mathrm{Al}_{2} \mathrm{O}_{3}\right)$ are studied such as:

Effect of $\mathrm{H}_{2} \mathrm{SO}_{4}$ acid concentration; the concentration of $1,2,3$ and $4 \mathrm{M}$, at a constant (flow rate $(2 \mathrm{ml} / \mathrm{min})$, stirring velocity $(500 \mathrm{rpm})$, time of reaction $(1.5 \mathrm{hr})$ and $\mathrm{pH}(2)$.

Effect of reaction time: $0.5,1$ and $2 \mathrm{hrs}$ are selected time intervals with a constant (flow rate $(2 \mathrm{ml} / \mathrm{min})$., stirring velocity (500rpm), $\mathrm{H}_{2} \mathrm{SO}_{4}$ concentration (3M), and $\mathrm{pH}(2)$.

Effect of flow rate: 1,2,3 and $4 \mathrm{ml} / \mathrm{min}$ were chosen as follow rate intervals with a constant (time of reaction is $\left(1.5 \mathrm{hr}\right.$ ), stirring velocity (500rpm), $\mathrm{H}_{2} \mathrm{SO}_{4}$ concentration (3M), and $\mathrm{pH}(2)$.

Effect of pH: 2, 3. 4 other parameters was constant (time of reaction $1.5 \mathrm{hr}$ and stirring velocity $500 \mathrm{rpm})$.

Then select the optimum conditions on bench scale water treatment (Jar Test) in surface water treatment: raw water (representative samples from Nile River), as well as sewage water treatment: sewage water used in this experiment was collected from representative samples.

\section{Preparations of PAIHS $^{\mathrm{TM}}$ and PAIHSSi ${ }^{\mathrm{TM}}$ from Alum}

Rice husk ash (RHA), was produced by calcination of rice husk (RH) for $2 \mathrm{~h}$ at $650{ }^{\circ} \mathrm{C}$, RHA is used as precursor of Sodium silicate , named as ( $\mathrm{SSi}$ ) as described by (Abo-El-Enein, et al., 2011). PAlHS $^{\mathrm{TM}}$ and PAlHSSi ${ }^{\mathrm{TM}}$ were produced as described by (Abo-El-Enein,et al., 2011). except for the precursor is leached Alum. SSi and RHA samples were characterized as described by (Abo-El-Enein, et al., 2011).

\section{Characterization of PAIHS $^{\mathrm{TM}}$ and PAIHSSi ${ }^{\mathrm{TM}}$}

PAlHS $^{\mathrm{TM}}$ and PAlHSSi ${ }^{\mathrm{TM}}$ were characterized using ionic chromatography, model Dionex ICS-6000, X-ray diffraction (XRD) Philips APD-3720 diffractometer with $\mathrm{Cu} \mathrm{K} \alpha$ radiation $(40 \mathrm{kV}, 40 \mathrm{~mA})$ and wavelength $(\lambda)=1.54 \AA$., Fourier transform infra red (FTIR) using Jasco FT/IR 460 plus spectrometer in the 400- 
$4000 \mathrm{~cm}^{-1}$ of FTIR and $4000-7500 \mathrm{~cm}^{-1}$ of NFTIR wave number ranges. As well as high resolution electron microscope (JOEL JEM-100S).

\section{Preparations of working solutions of CA, LA PAIHS ${ }^{\mathrm{TM}}$ and PAIHSSi $^{\mathrm{TM}}$}

Each material of CA, LA PAlHS ${ }^{\mathrm{TM}}$ and PAlHSSi ${ }^{\mathrm{TM}}$ dried at $105^{\circ} \mathrm{C}$ for $2 \mathrm{hrs}$, then weight $1 \mathrm{gm}$ of each material, then dissolved in $1000 \mathrm{ml}$ of double distilled water (each $\mathrm{ml}=1 \mathrm{mg} / \mathrm{l})$, then use these solutions in jar test experiments.

\section{Chemical treatment applications:}

\section{Removal of turbidity of surface water:}

The prepared samples of LA, PAlHS ${ }^{\mathrm{TM}}$ and PAlHSSi ${ }^{\mathrm{TM}}$ are utilized for turbidity removal of a certain representative samples of intake of Nile river compared with commercial Alum(CA).

Each one liter of raw water was mixed with 2-12 ppm in with CA, LA, PAlHS $^{\mathrm{TM}}$ and PAlHSSi ${ }^{\mathrm{TM}}$ and agitated for 1 minute rapid mixing $(200 \mathrm{rpm})$, followed by slow mixing for 5 minutes $(30 \mathrm{rpm})$ and 20 minutes standing time. The concentration of turbidity was measured by turbidity meter model, TL2300, HACH/Germany in raw and purified samples according to (APHA,2005) and then the optimum conditions were recorded.

\section{Reduction of sewage water pollution indicators:}

The prepared samples of LA, PAlHS ${ }^{\mathrm{TM}}$ and $\mathrm{PAlHSSi}^{\mathrm{TM}}$ are utilized for reduction of COD, BOD and TSS from representative samples of sewage water. Each one liter of raw water was mixed with (8-48) ppm with LA, PAlHS ${ }^{\mathrm{TM}}$ and PAlHSSi ${ }^{\mathrm{TM}}$ and agitated for one minute at rapid mixing $(200 \mathrm{rpm})$, followed by slow mixing for 5 minutes $(30 \mathrm{rpm})$ and 20 minutes standing time. The concentration of each parameter was measured in raw and treated samples according t, (APHA, 2005) and then the optimum conditions were recorded.

\section{RESULTS AND DISCUSSION}

\section{Factors affecting the productivity of $\mathrm{Al}_{2} \mathrm{O}_{3}$ : Effect of $\mathrm{H}_{2} \mathrm{SO}_{4}$ concentration Solution:}

Fig. (1): shows the influence of different concentration of sulfuric acid $\left(\mathrm{H}_{2} \mathrm{SO}_{4}\right)$ soln. used 5, 10, $15 \%$, other items are fixed (flow rate $2 \mathrm{ml} / \mathrm{min}$., stirring velocity 500 $\mathrm{rpm}$, time of reaction is $1.5 \mathrm{hrs}$. and final $\mathrm{pH} 2$ ), the result showed that as power of acid increases the productivity content of Alum increases and reached to upper productivity at the concentration of acid (3M).

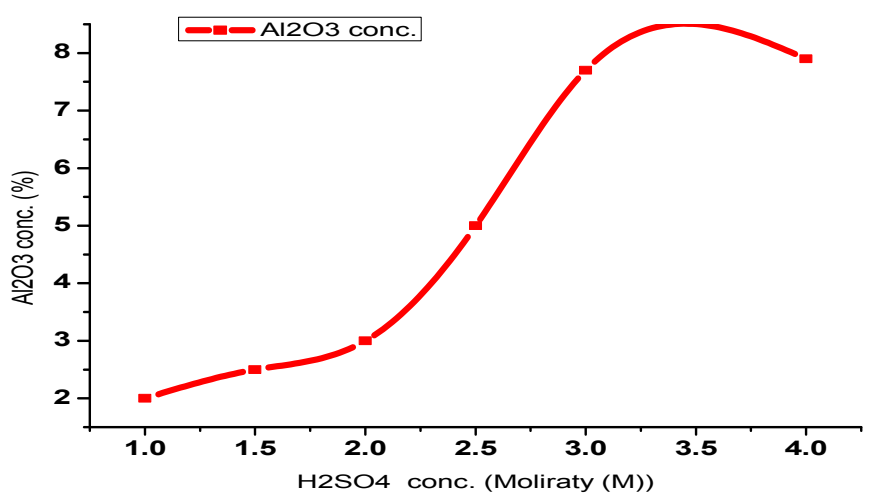

Fig. 1: Effect of $\mathrm{H}_{2} \mathrm{SO}_{4}$ conc. on $\mathrm{Al}_{2} \mathrm{O}_{3}$ productivity 


\section{Effect of reaction time}

Fig. (2): shows the effect of three reaction times was experimented $0.5,1$, and 2 hours, other parameters are constant (flow rate $2 \mathrm{ml} / \mathrm{min}$., stirring velocity $500 \mathrm{rpm}$, $3 \mathrm{M} \mathrm{H} \mathrm{H}_{2} \mathrm{SO}_{4}$ soln. and final $\mathrm{pH}$ 2) the result showed that as time increases the content of $\mathrm{Al}_{2} \mathrm{O}_{3}$ increases.

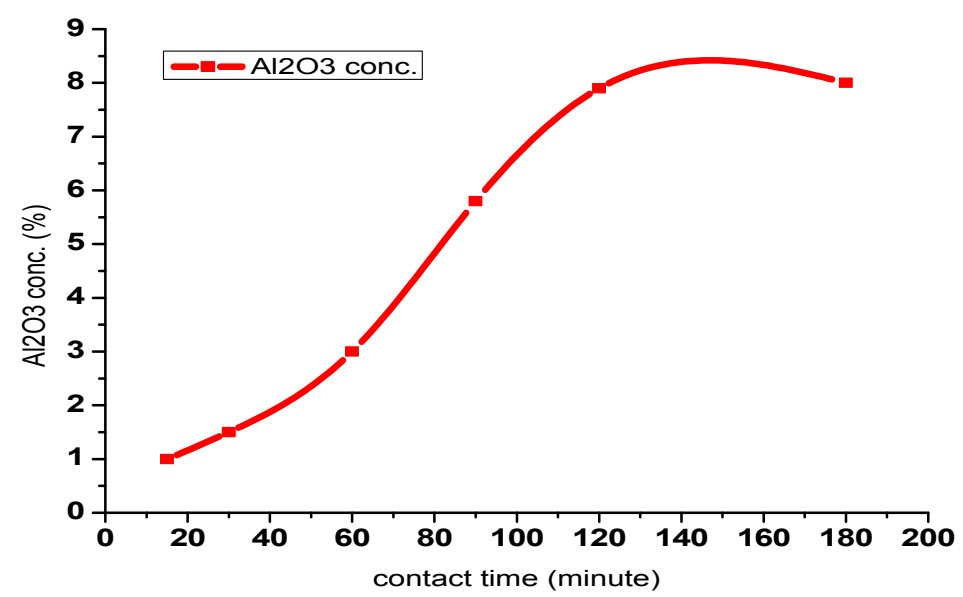

Fig. 2: Effect of contact time on $\mathrm{Al}_{2} \mathrm{O}_{3}$ productivity

\section{Effect of flow rate}

Fig. (3): shows the effect of four different flow rates addition of $\mathrm{H}_{2} \mathrm{SO}_{4}$ on sludge sample was experimented 1,2,3 and $4 \mathrm{ml} / \mathrm{min}$, the result showed that as flow rates increases the content of $\mathrm{Al}_{2} \mathrm{O}_{3}$ decreases.

The current Fig.ures showed that the optimum conditions which gives the best conc. of $\mathrm{Al}_{2} \mathrm{O}_{3}(7.8 \%)$ are conc., $\mathrm{H}_{2} \mathrm{SO}_{4} 3 \mathrm{M}$, flow rate $1 \mathrm{ml} / \mathrm{l}$ and reaction time $2 \mathrm{hrs}$, which named as LA, LA characterized and then used as coagulant in water and sewage waste water treatment.

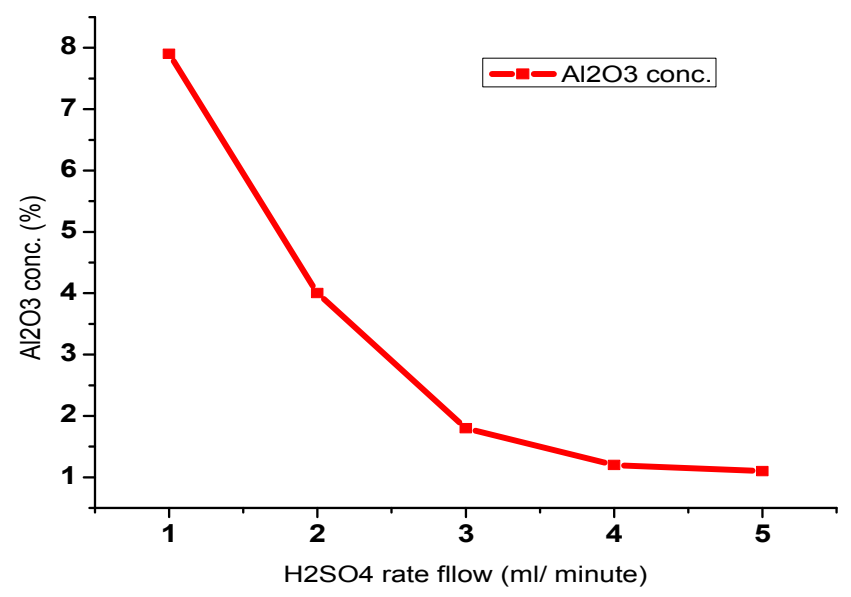

Fig. 3: Effect of flow rate on $\mathrm{Al}_{2} \mathrm{O}_{3}$ productivity

\section{Characterization of LA}

Table (1) it showed that, there is no variation of the constituents of LA or CA, except for the presence of iron content is $1.79 \%$ in LA, which enhances of the coagulation process. 
Table 1: Physicochemical characteristics of LA and CA

\begin{tabular}{lll}
\hline Parameters & (LA) & (CA) \\
\hline Specific gravity(sp.gr) & 1.41 & 1.37 \\
$\mathrm{Al}_{2} \mathrm{O}_{3} \%$ & 7.9 & 8.2 \\
$\mathrm{Al}$ conc. \% & 4.08 & 4.2 \\
$\mathrm{Fe}$ conc. \% & 1.81 & 0.02 \\
\hline
\end{tabular}

Fig. (4-a) Shows the FTIR spectrum of poly aluminum hydroxy sulphate $\left(\mathrm{PAHS}^{\mathrm{TM}}\right)$. The spectrum displayed the characteristic bands for $\mathrm{OH}$-stretching, $\mathrm{H}_{2} \mathrm{O}$ bend Al-OH $\mathrm{OH}_{2}$ bend, Al-O symmetric stretch, $\mathrm{SO}_{4}$ and Al-O bending at 3372, 1671, 1135,606 and $505 \mathrm{~cm}^{-1}$, respectively [14-15] Fig. (4-b) shows the FTIR spectrum of poly aluminum hydroxy sulphate silicate $\left(\mathrm{PAHSSi}^{\mathrm{TM}}\right)$. The spectrum displayed the characteristic bands for Si-OH stretching, OH-stretching, $\mathrm{H}_{2} \mathrm{O}$ bend $\mathrm{Al}-\mathrm{OH}_{2},(\mathrm{Si}-\mathrm{O}$ stretching, Al-O symmetric stretch), $\mathrm{SO}_{4}$ and/or Al-O-Si and Al-O bending at 3720, $3376,1651,1129,609$ and $456 \mathrm{~cm}^{-1}$, respectively, (Kloprogge 2000) and (Kloprogge 1999).

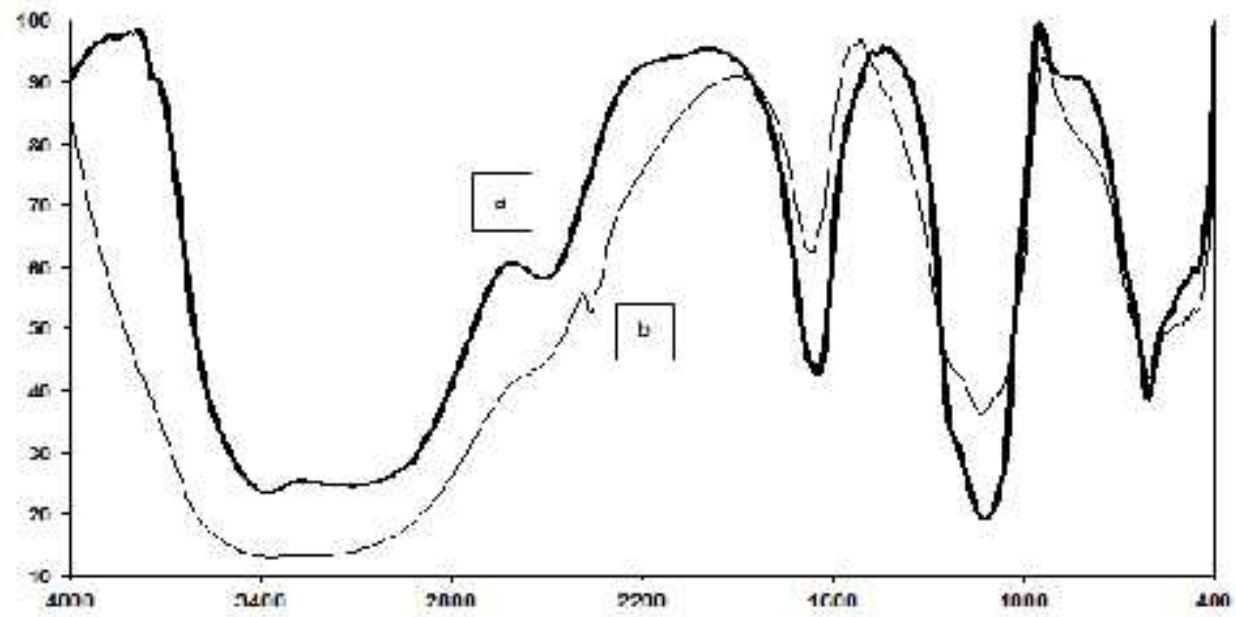

Fig. (4 a and b): FTIR spectra (a): PAHS and (b): PAHSSi

Fig.(5) shows the SEM micrograph obtained for PAHS ${ }^{\mathrm{TM}}$ sample which indicated the monoclinic and rectangular crystalline form, with black spot which may be refer to iron oxide.

Fig. (6) shows the SEM micrograph obtained for PAHSSi ${ }^{\mathrm{TM}}$ sample which indicated the dispersed monoclinic and rectangular crystalline form, with black spot which may be refer to iron oxide, as well as fine spots due to the presence of activated silica.

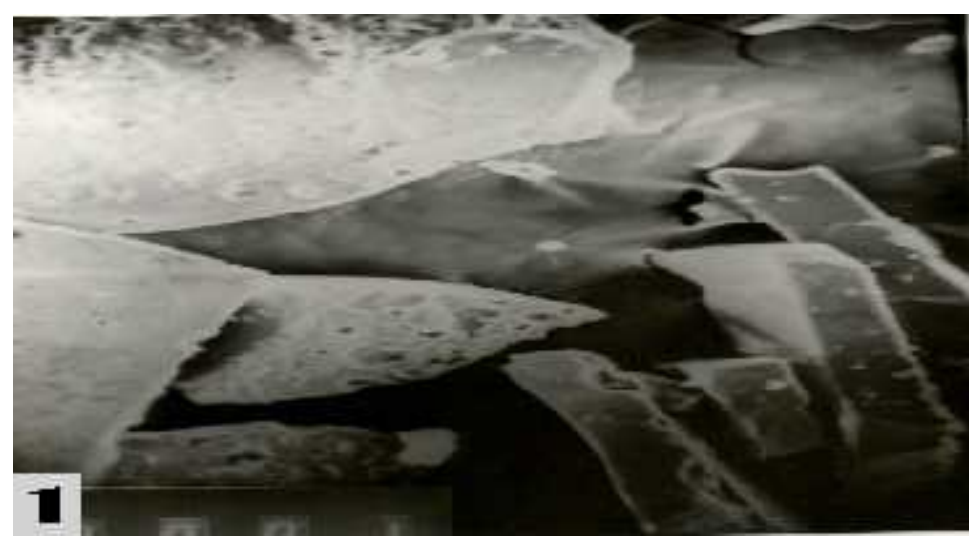

Fig. 5: SEM micrograph of PAHS. 


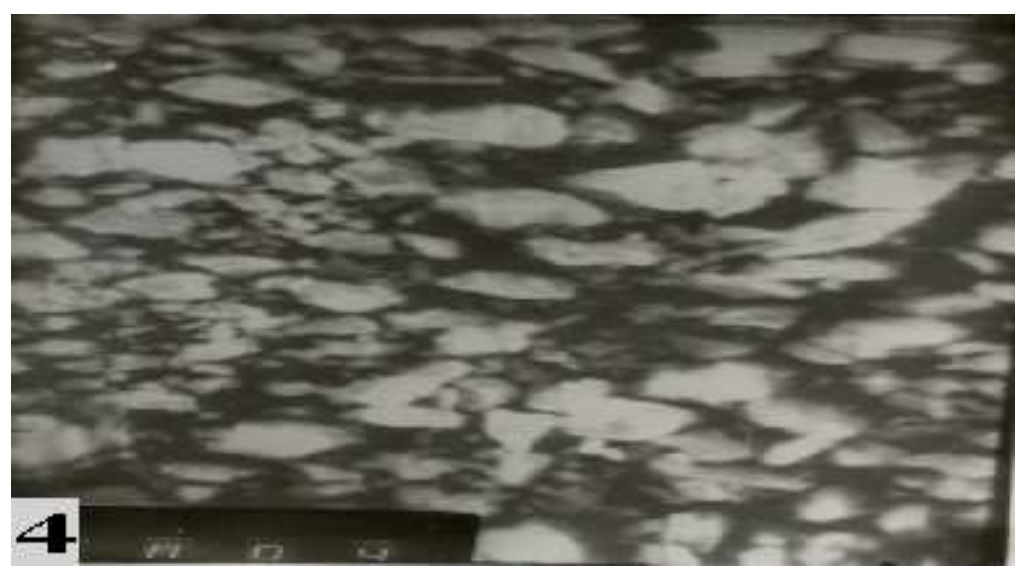

Fig.6: SEM micrograph of PAHSSi

Fig. (7) describes the X-ray diffractogram of poly aluminum hydroxy sulphate silicate (PAHSSi), which indicates the amorphous silica broad band appeared around $2 \theta$ equal to $22^{\circ}$. The abroad peaks appeared in the range of $2 \theta$ from 5 to $25^{\circ}$ indicated that there is $\mathrm{Al}_{13}$ species in $\mathrm{PACl}-\mathrm{Al}_{13}$ and the amorphous character of the sulphate salt ( Abo-El-Enein et al., 2011)

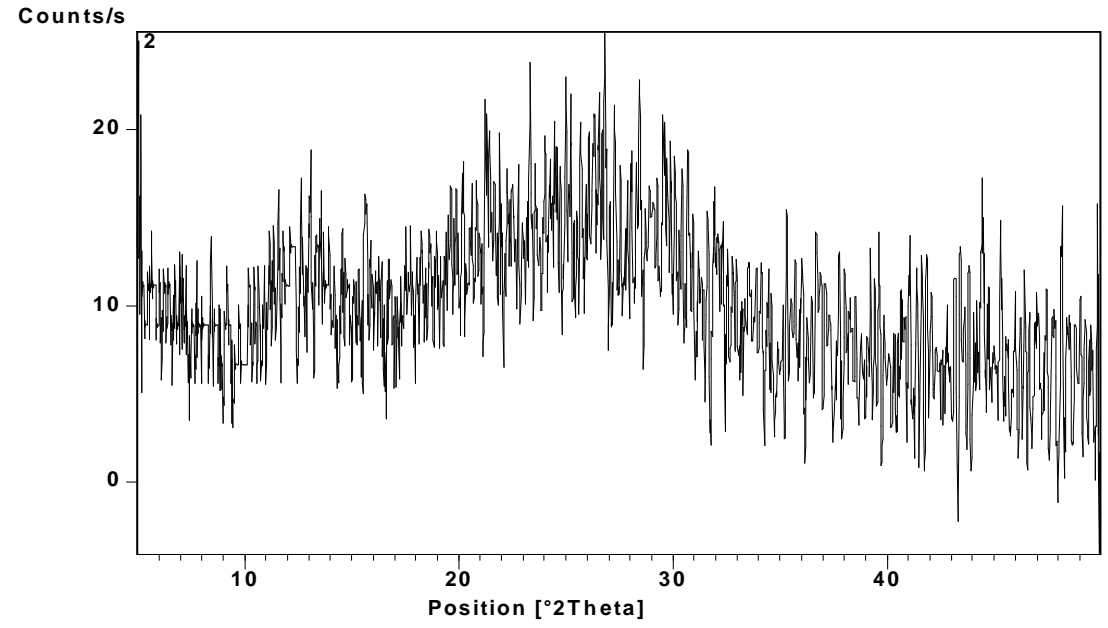

Fig. 7: XRD pattern of PAHS

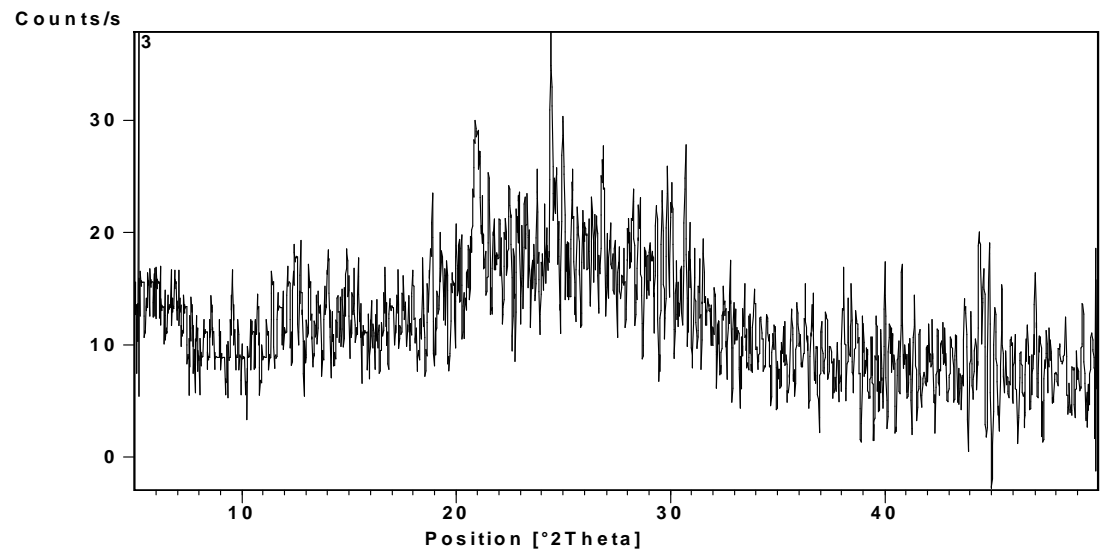

Fig. 8: XRD pattern of PAHSSi 


\section{Chemical treatment Application \\ Surface water treatment}

The data listed in Table (2), Fig.(9) and Fig.(10) were summarized the variations of TDS, Turbidity and $\mathrm{pH}$ of surface water before and after purification of representative samples . displayed the variation and removal percentage of turbidity using different co-agulants, it was found that the maximum removal percentage and minimum turbidity were $95 \%$ and $0.2 \mathrm{NTU}$, respectively when PAlHSSi ${ }^{\mathrm{TM}}$ was used, where, Fig. (11) display the optimum dose coagulant required to reach the acceptable turbidity level it was found that the minimum dose was $(4 \mathrm{mg} / \mathrm{l})$ using PAlHSSi ${ }^{\mathrm{TM}}$. It was found also, the turbidity after purification with all coagulants within permissible limits of Egyptian standards (1NTU).

Table 2: Variations of some physicochemical items of water before and after purification of area under study

\begin{tabular}{|c|c|c|c|c|c|c|}
\hline \multirow{2}{*}{$\begin{array}{l}\text { Coagulant } \\
\text { Parameters }\end{array}$} & \multirow{2}{*}{$\begin{array}{c}\text { Before } \\
\text { Purification }\end{array}$} & \multicolumn{4}{|c|}{ After purification } & \multirow{2}{*}{$\begin{array}{c}\text { Permissible } \\
\text { limits }\end{array}$} \\
\hline & & $\mathrm{CA}$ & LA & PAlHS $^{\mathrm{TM}}$ & PAlHSSi $^{\text {TM }}$ & \\
\hline TDS $(\mathrm{mg} / \mathrm{l})$ & 118 & 130 & 135 & 125 & 122 & $<1000$ \\
\hline Turbidity ( NTU) & 4 & 0.9 & 0.8 & 0.4 & 0.2 & $<1$ \\
\hline$p H$ & 7.65 & 7.45 & 7.47 & 7.50 & 7.52 & $6.5-8.5$ \\
\hline
\end{tabular}

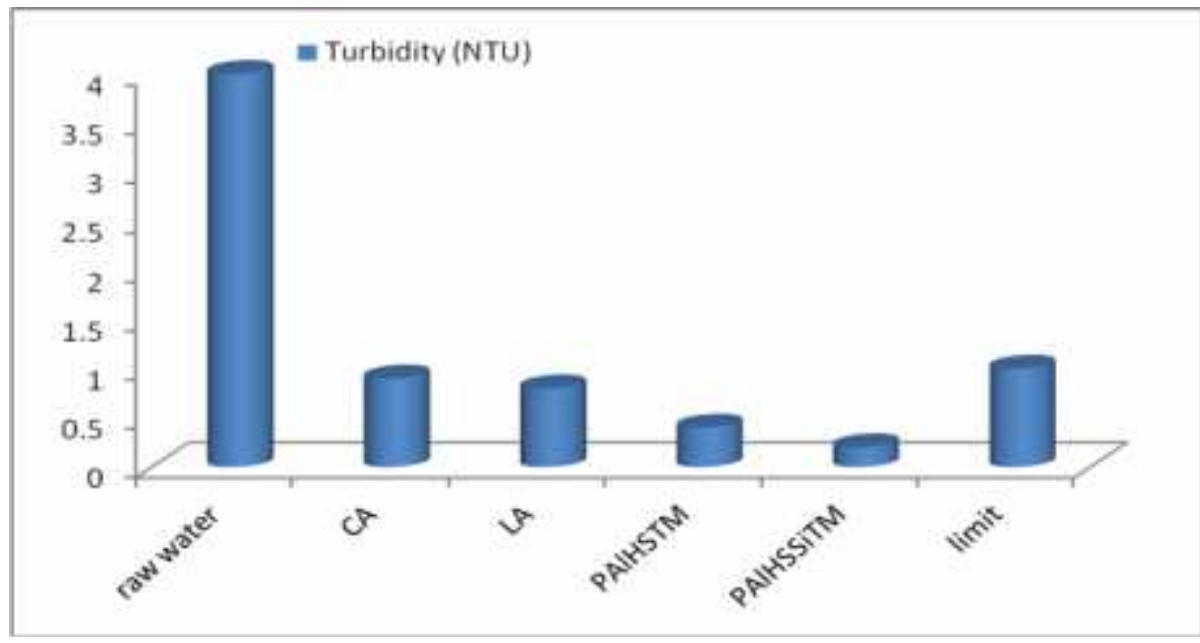

Fig. 9: Variation of turbidity (NTU) versus different co-agulants

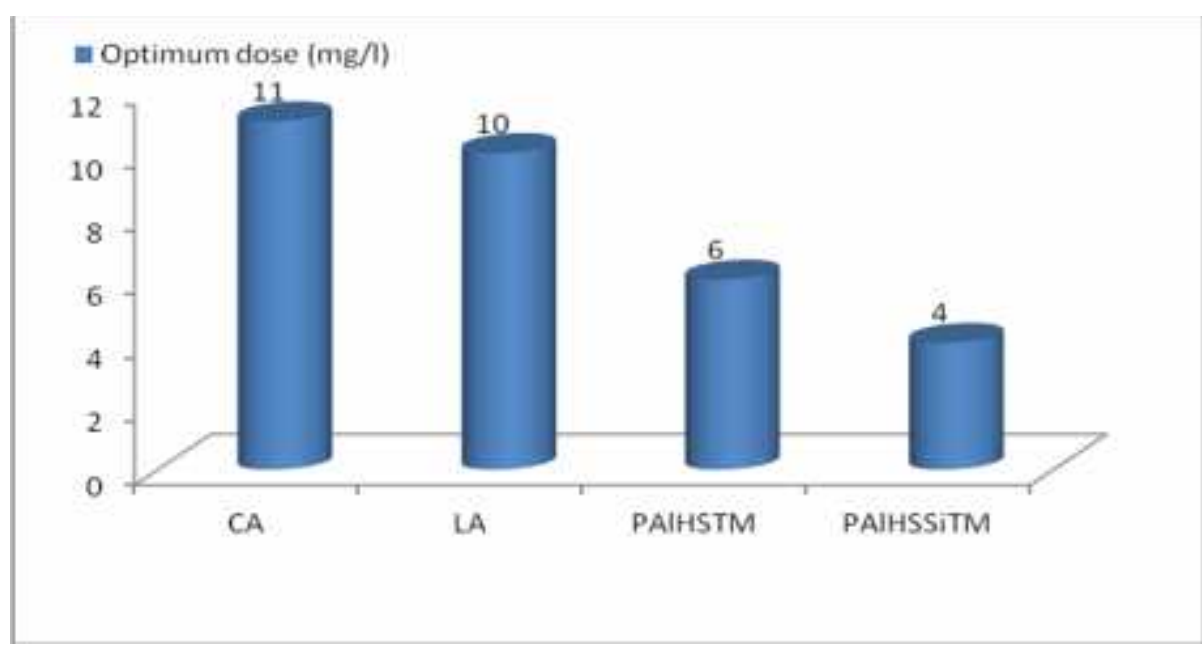

Fig. 10: Turbidity (NTU) removal percentages for different co-agulants 


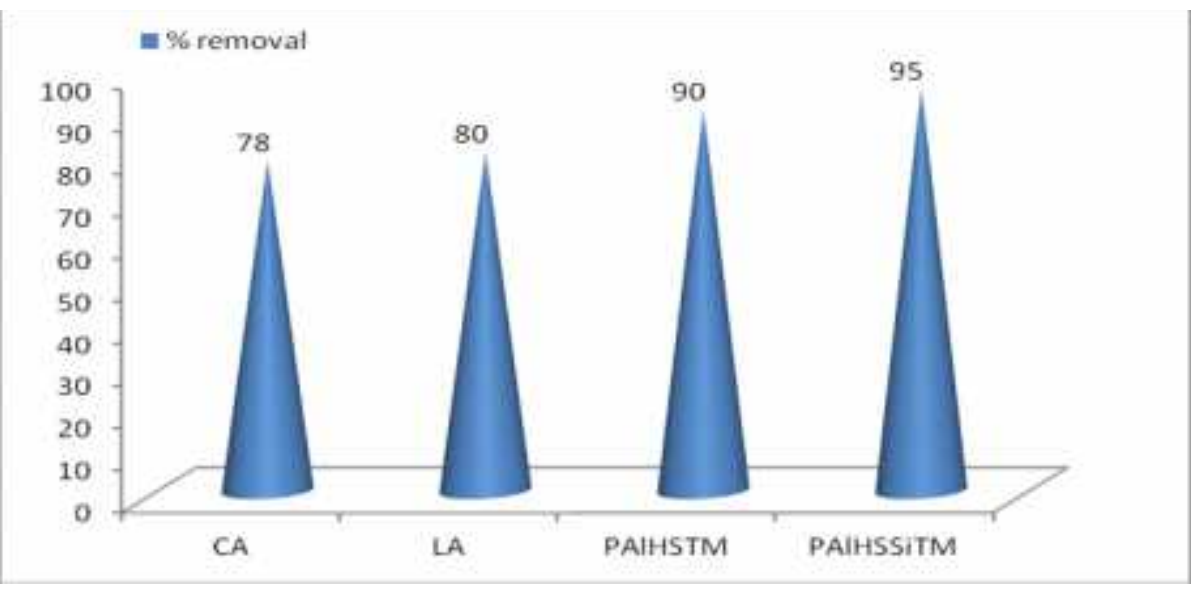

Fig. 11: Optimum dose (mg/l) detection of different co-agulants for water purification

\section{Sewage waste water}

The data listed in Table: (3), Fig. (12) and Fig. (13) summarized the variations of TSS, COD and BOD of sewage water before and after treatment of representative samples. It was found that the maximum removal percentage TSS, COD and BOD were 97,91, and 92 respectively when $\mathrm{PAlHSSi}^{\mathrm{TM}}$ was used, where, Fig. (14) display the optimum dose coagulant required to reach the acceptable levels of TSS, COD and $\mathrm{BOD}$, the minimum dose was $(24 \mathrm{mg} / \mathrm{l})$ using PAlHSSi ${ }^{\mathrm{TM}}$. It was found also that, the maximum removal of TSS, COD and BOD in sewage water reached $94 \%, 85 \%$ and $85 \%$ respectively using LA, the maximum removal of TSS, COD and BOD in sewage water reached $96 \%, 89 \%$ and $90 \%$ respectively using PAlHS $^{\mathrm{TM}}$, the maximum removal of TSS, COD and BOD in sewage water reached 97\%,91\% and $92 \%$ respectively using PAlHSSi ${ }^{\mathrm{TM}}$, the maximum removal of TSS, COD and BOD of sewage water reched 90,92,93\% using PAlFeClSi (Abo-El-Enein et al., 2011) All parameters after treatment were compatible with international and Egyptian standards.

Table 3: Variations of Sewage water indicators versus different co-agulants

\begin{tabular}{|c|c|c|c|c|c|c|c|c|}
\hline \multirow{2}{*}{\multicolumn{3}{|c|}{$\overbrace{\text { Parameters }}^{\text {Coagulant }}$}} & \multirow{3}{*}{$\begin{array}{c}\begin{array}{c}\text { Before } \\
\text { treatment }\end{array} \\
1220\end{array}$} & \multicolumn{4}{|c|}{ After treatment } & \multirow[b]{2}{*}{$\begin{array}{l}\text { Permissible } \\
\text { limits }\end{array}$} \\
\hline & & & & CA & LA & PAIHS $^{\text {TM }}$ & PAIHSSi $^{\text {TM }}$ & \\
\hline \multirow[t]{3}{*}{ TDS } & $\mathrm{mg} / \mathrm{l}$ & & & 1300 & 1295 & 1250 & 1240 & $<2000$ \\
\hline & TSS & $\mathrm{mg} / \mathrm{l}$ & 240 & 20 & 15 & 8 & 7 & $<40$ \\
\hline & & pH & 7.05 & 7.15 & 7.21 & 7.40 & 7.45 & $6.0-9.0$ \\
\hline \multirow[t]{2}{*}{ COD } & mg/l & & 380 & 55 & 60 & 40 & 34 & $<80$ \\
\hline & BOD & $\mathrm{mg} / \mathrm{l}$ & 290 & 38 & 45 & 30 & 25 & $<40$ \\
\hline
\end{tabular}

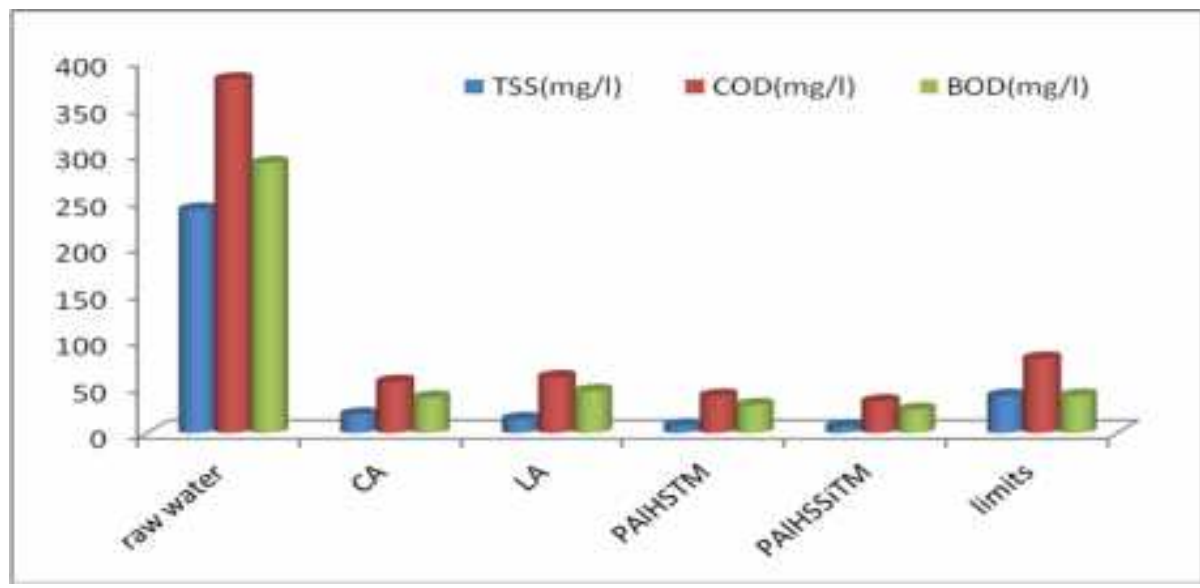

Fig. 12: Variations of COD, BOD and TSS versus different co-agulants 


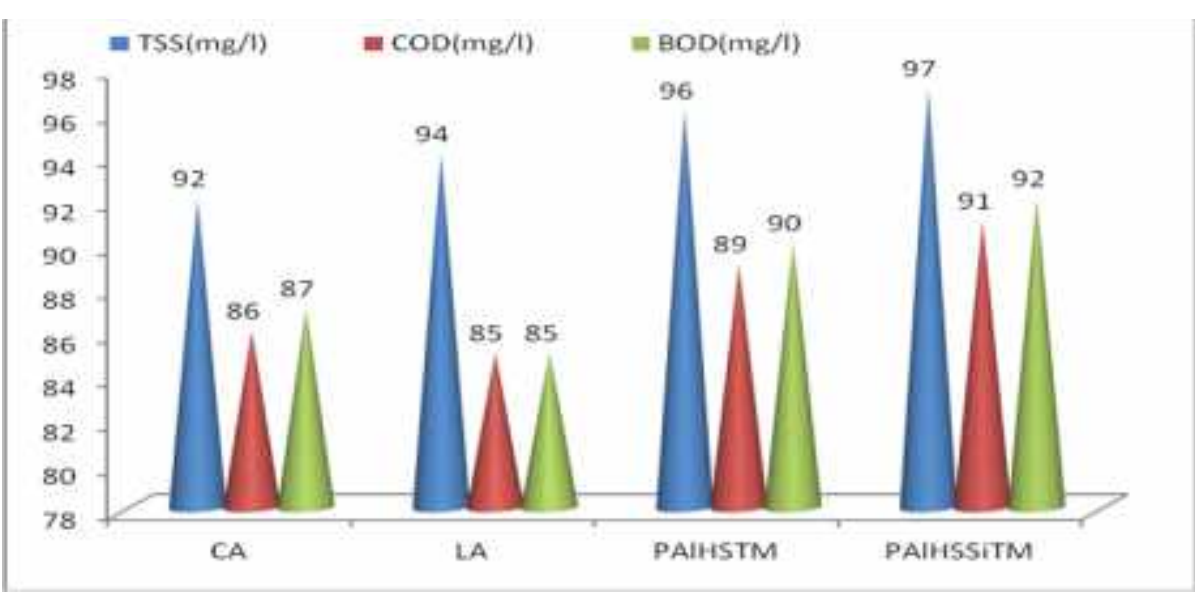

Fig. 13: TSS, COD and BOD removal percentages versus different co-agulants

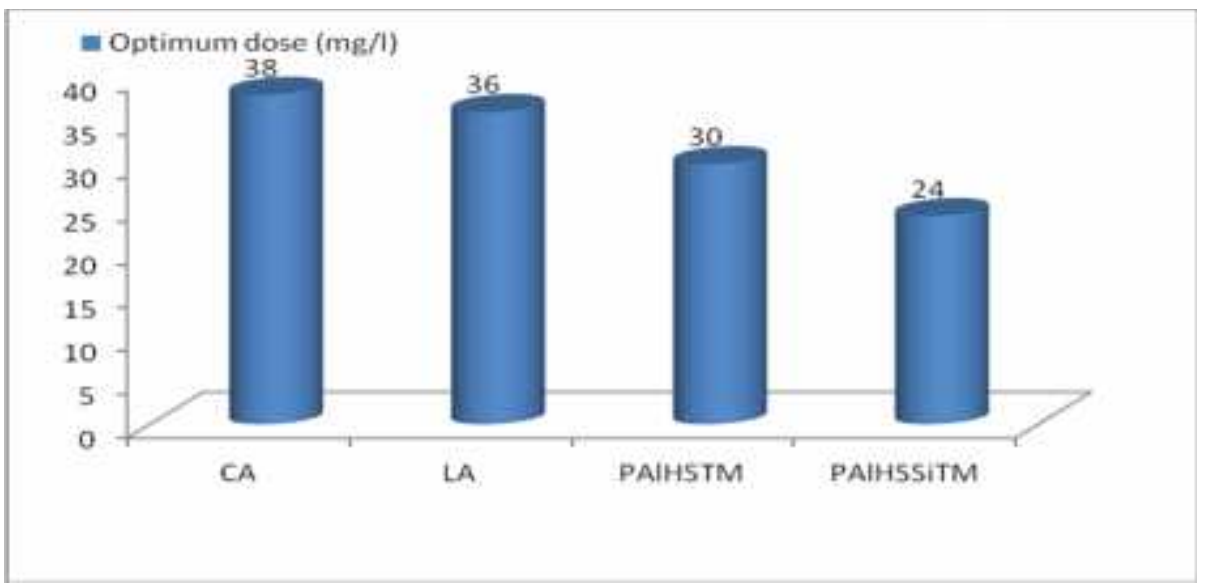

Fig. 14: Optimum dose (mg/l) detection of different co-agulants for sewage water treatment

\section{CONCLUSION}

Acidification can effectively recover (leach) alum from sludge of water treatment. The optimum condition of reaction between dried sludge and $\mathrm{H}_{2} \mathrm{SO}_{4}$ which yield leached alum with good conc. of $\mathrm{Al}_{2} \mathrm{O}_{3}(7.8 \%)$ which is very close to Egyptian standard for commercial alum LA and CA are used in removal some pollutants such as turbidity in drinking water; COD, BOD, TSS in sewage waste water, no variation of removal percentages in the case of LA or CA, the maximum removal of TSS, COD and BOD in sewage water reached $96 \%, 89 \%$ and $90 \%$ respectively using PAlHS ${ }^{\mathrm{TM}}$, the maximum removal of TSS, COD and BOD in sewage water reached $97 \%, 91 \%$ and $92 \%$ respectively using PAlHSSi ${ }^{\mathrm{TM}}$ the values of pollutants after treatment are comply with Egyptian standards for drinking and sewage water regulations and no considerable variation of dissolved solids and $\mathrm{pH}$ after treatment and all within limits of regulations. Finally study showed be a better way to reuse sludge of water treatment as coagulant which leading to reduce landfill disposal, cost effectiveness. as well as saves precious natural resources.

\section{ACKNOWLEDGEMENT}

The authors are thankful to Faculty of Earth Sciences, Beni- Suef University, Egypt and holding company for water and waste water as well as Qena and Matrouh Company for water and waste water. 


\section{REFERENCES}

Abdo, M.S.E.; Ewida, K.T. and Youssef, Y.M. (1993). Recovery of alum from wasted sludge produced from water treatment plants, J. Environ. Sci. Health., 28: 1205-1216.

Abo-El-Enein S.A.; Eissa M.A, Diafullah H.A. Rizk, M.R. and Mohamed.F.M.. (2011), Utilization of a low cost agro- residue for production of coagulant aids and their applications, J. Haz. Mater., 172: 574-57.

Allouche, L.; Huguenard, C. and Taulelle, F. (2001). 3QMAS of three aluminum polycations: space group consistency between NMR and XRD, J. of Physics and Chemistry of Solids, 62: 1525-1531.

Holding company for water and waste water. (2019). Annual report, Ministry of Housing, Utilities and Urban Communities (MOHUUC), Egypt.

APHA (2005). Standard Methods for the Examination of Water and Wastewater, 19 th edition.

Babatunde, A.O; Zhao, Y.Q. Burke, A.M and Morris, M.A. (2009). Characterization of aluminum-based water treatment residual for potential phosphorous removal in engineered wetlands, J. Environ. Pollut., 157: 2830-2836.

Bishop, M.M; Rolan,A.T, Bailey, T.L and Cornwell,D.A. (1987). Testing of alum recovery for solids reduction and reuse, J. AWWA, 79: 76-83.

Bui, H. M. and Duong, H. T. G. (2017). Coagulation for Treatment of Swine Slaughterhouse Wastewater, J. Geo Sci. Eng., 63 : 15-21.

Christensen, E; Hakonsen.T; Lucy Robertson,J. and M. Myrmel (2016). Zirconium and Chitosan coagulants for drinking water treatment - a pilot, journal of water supply: research and technology, J. water supply: research and technology, 65:635-644.

Chu, W. (1999). Lead metal removal by recycled alum sludge, Water Res., 33: 3019_ 3025 .

Chubar, N.I and Kaniboltsky,V.A. (2005). Adsorption of phosphate ions on novel inorganic ion exchangers, Colloid Surface, A255: 55-63.

Cornwell, D. and Susan,J. (1979). Characteristics of acid-treated alum sludges, J. AWWA , 71: 604-608.

Egyptian code for water purification.(1998). Hand book, first ed. Arab republic of Egypt.

Fulyon, P.G . (2005). Recover alum to reduce waste-disposal costs, J. AWWA, 66: 312-318.

Gasco', G ; Me'ndez. A, D. , Go'mez-Orea, G. (2005). Residuos 83:100.

Hu, J.; Chu, W.; Sui, M.; Xu, B.; Gao, N. and Ding, S. (2018). Comparison of Drinking Water Treatment Processes Combinations for the Minimization of Subsequent Disinfection By-Products Formation during Chlorination and Chloramination, Chem. Eng. J., 335: 352-361.

Kloprogge, J.; Huada, R.R. and Frost, L. (2000). Near-infrared spectroscopic study of $\left[\mathrm{AlO}_{4} \mathrm{Al}_{12}(\mathrm{OH})_{23}(\mathrm{H} 2 \mathrm{O})_{12}\right]^{+7}-\mathrm{O}-\mathrm{Si}(\mathrm{OH})_{3}$ nitrate crystals formed by forced hydrolysis of $\mathrm{Al}_{13}$ in the presence of TEOS, Spectrochimica Acta Part A., 56: 2405-2411.

Kloprogge, J.T. and Frost, R.L. (1999). Raman and infrared spectroscopic investigation of the neutralization of Aluminum in the presence of monomeric orthosilicic acid, Spectrochimica Acta Part A., 55: 1359-1369.

Li, C.W.; Lin, J.L. Kang, S.F. and Lang, C.L.(2005). Acidification and alkalization of textile chemical sludge, Sep. Purif. Technol., 42: 31-37. 
Midorkawa, I; Alki, H. and Omori, A. (2008). Recovery of high phosphorous from municipal waste water secondary effluent by a high -speed adsorbent, water Sci. technol., 58: 1601-1607.

Mohamed, F.M. (2009). treatment of some water pollutants using novel sorbent materials, PhD. Thesis, chemistry Dep. Fac. Of Sci., Ain Shams university.

Panswad, T.(1992). Aluminum recovery from industrial aluminum sludge, Water Supply, 10:159-166.

Sousa, V. S.; Corniciuc, C. and Teixeira, M. R. (2017). The Effect of $\mathrm{TiO}_{2}$ Nanoparticles Removal on Drinking Water Quality Produced by Conventional Treatment, C/F/S. Water Res., 109: 1-12.

Tolkou, A. K. and Zouboulis, A. I. (2014). Synthesis And Coagulation Performance Of Composite Poly-Aluminum-Ferric-Silicate-Chloride Coagulants In Water And Wastewater, Desal. and Water Treat., 53(12): 3309-3318.

Metcalf and Eddy. (2013). Wastewater engineering; treatment and resource recovery, fifth ed. McGraw Hill.

Metcalf and Eddy. (2003). Wastewater engineering; Treatment and reuse, fourth ed. McGraw Hill.

Mackenzie L.Davis. (2010). Water and Wastewater engineering; Design Principles, first ed. McGraw Hill.

Xu, G.R.; Zhang, W.T. and Li, G.B. (2005). Absorbent obtained from CEPT sludge in waste water chemically enhanced treatment, Water Res., 39: 5175-5185. 